\title{
Quantitative Measurement of the Chemical Composition of Fatty Acid of Cocoa Butter and the Isotopic Content of Glycerol Contained in Cocoa Butter by the NMR ${ }^{13} \mathrm{C}$ from the INEPT Sequence and Characterization of the Geographical Origin of the Cocoa
}

\author{
Didier Diomandé ${ }^{1,2^{*}}$, Tiemoko Touré Dro ${ }^{3}$, Jacques Sagne Akpa1, \\ Silvestre Virginie ${ }^{2}$, Illa Tea ${ }^{2}$, Gérald S. Remaud ${ }^{2}$ \\ ${ }^{1}$ Laboratoire de Constitution et Réaction de la Matière de l’Université Félix Houphouët-Boigny, Abidjan, Côte d'Ivoire \\ ${ }^{2}$ Chimie et Interdisciplinarité, Synthèse, Analyse, Modélisation (CEISAM), Nantes, France \\ ${ }^{3}$ Laboratoire des Sciences de la Matière, de l'Environnement et de l'énergie Solaire, Université Félix Houphouët-Boigny, Abidjan, \\ Côte d'Ivoire \\ Email: *dggbe@yahoo.fr
}

How to cite this paper: Diomandé, D., Dro, T.T., Akpa, J.S., Virginie, S., Tea, I. and Remaud, G.S. (2022) Quantitative Measurement of the Chemical Composition of Fatty Acid of Cocoa Butter and the Isotopic Content of Glycerol Contained in Cocoa Butter by the NMR ${ }^{13} \mathrm{C}$ from the INEPT Sequence and Characterization of the Geographical Origin of the Cocoa. American Journal of Analytical Chemistry, 13, 79-95.

https://doi.org/10.4236/ajac.2022.133007

Received: November 23, 2021

Accepted: March 4, 2022

Published: March 7, 2022

Copyright ( 2022 by author(s) and Scientific Research Publishing Inc. This work is licensed under the Creative Commons Attribution International License (CC BY 4.0).

http://creativecommons.org/licenses/by/4.0/

\begin{abstract}
The determination of the chemical composition of cocoa butter and the isotopic contents of the carbons (C-2, C-1 and C-3) of the glycerol contained in the cocoa butter were measured by the NMR- ${ }^{13} \mathrm{C}$ from the INEPT sequence. This technique has already been applied to triglycerides of animal origin. Thus, cocoa butter is made up of nearly $66 \%$ saturated fatty acid composed mainly of stearic acid and palmitic acid. Monounsaturated fatty acids represented by oleic acid have an average content of $31 \%$ and polyunsaturated fatty acids represent less than $4 \%$. Likewise, the isotopic contents of the glycerol of the triglycerides of cocoa butter in ${ }^{13} \mathrm{C}$ of the carbons C-2, C-1 and C-3 were measured directly and values vary from $-11 \%$ to $-19 \%$ for the $\mathrm{C}-2$ and from $-39 \%$ to $-41 \%$ for all C-1 and C-3 because of the symmetry of glycerol.
\end{abstract}

\section{Keywords}

Chemical Composition, Cocoa Butter, INEPT, Isotopic Content 
things [1]. Lipids are used in cosmetics, pharmaceuticals and human food. Lipids are constituents of cell membranes, inter and intracellular messengers and an energy reserve for the human body [2] [3]. The form of lipids present in the body is that of fatty acid triglycerides. Fatty acids can be divided into three classes: saturated, monounsaturated and polyunsaturated. Unsaturated fatty acids, in particular oleic acid and linoleic acid, play an essential nutritional role. They have a preventive action against cardiovascular disease by lowering cholesterol levels, which is not the case for certain saturated fatty acids [4]. The chemical composition in fatty acids is linked to the botanical or animal origin or to the processes used to obtain it, but also to the geographical origin [5]. Today's society is demanding on the origin of the products consumed. Thus each actor, from the product to the consumer, wants the origin of the animal or vegetable fats used to be guaranteed, whether in a raw or processed product, in order to control its quality. It is therefore in this sense that this work is part of the determination of the fatty acid composition but also of the determination of the ${ }^{13} \mathrm{C}$ isotopic signature of the glycerol contained in cocoa butter by the ${ }^{13} \mathrm{C}$-INEPT method. This technique has already made it possible to analyze triacylglycerols in olive oil and also to quantify several fatty acids, triglycerols in egg yolks [6].

\section{Materials and Methods}

\subsection{Preparation of the Sample}

We worked on 41 samples from 21 producing countries. These samples were provided by the International Agricultural Research Center for Development (CIRAD) and those from Côte d'Ivoire were obtained from farmers in different producing regions. Cocoa butter is extracted from the cocoa beans separated from the shells. $10 \mathrm{~g}$ of cotyledons are finely ground and the powder obtained is extracted hot $\left(90^{\circ}\right)$ at reflux, for 2 hours, with $(3 \times 100 \mathrm{~mL})$ of cyclohexane (Prolabo). Other solvents such as hexane, acetone can also be used for the extraction of cocoa butter. After cooling and filtration, the residue constitutes lean cocoa. The filtrate is evaporated and gives cocoa butter ( $45 \%$ to $50 \%)$. After separation on a vacuum pump to remove traces of cyclohexane, a mass of 403.2 $\mathrm{mg}$ of cocoa butter is dissolved in $630 \mathrm{mg}$ of $\mathrm{CDCl}_{3}$ (Eurisotop). The solution is well homogenized and then introduced into a $5 \mathrm{~mm}$ diameter NMR tube.

\subsection{Isotopic ${ }^{13} \mathrm{C}$ NMR Acquisition Parameters}

Carbon has two isotopes, ${ }^{12} \mathrm{C}$, which has an isotopic abundance of about $98.9 \%$, and ${ }^{13} \mathrm{C}$, which is only $1.1 \%$. In the ${ }^{13} \mathrm{C}$ NMR study, the spectrum obtained gives low intensities, which does not allow spectrum analysis. In order to obtain a spectrum favorable to the analysis, polarization transfers from hydrogen to carbon-13 are carried out, among the polarization transfer techniques we use INEPT (Insensitive Nuclei Enhanced by Polarization Transfer). The INEPT or Insensitive Core Reinforced by Polarization Transfer provides a spectrum favorable to analysis by proceeding by polarization transfer from ${ }^{1} \mathrm{H}$ to ${ }^{13} \mathrm{C}$. In 
INEPT, the variation of the pulse angle depends on the chemical shift and the $\mathrm{J}_{\mathrm{C}-\mathrm{H}}$ decoupling constant, hence the presence of signal distortion caused by different couplings present. The principle can be broken down as follows, we have the ${ }^{1} \mathrm{H}$ excitation which firstly allows the polarization to be transferred from ${ }^{1} \mathrm{H}$ to ${ }^{13} \mathrm{C}$ and secondly to detect information on the ${ }^{13} \mathrm{C}$ nucleus. The start of this sequence is a spin echo that inverts the population of a subpopulation of protons resulting in carbon selectivity. This results in a gain in intensity of the ${ }^{13} \mathrm{C}$ signals. The linear combinations of these different spectra then make it possible to separate the $\mathrm{CH}, \mathrm{CH}_{2}$ and $\mathrm{CH}_{3}$ sub-spectra. However, this assumes that all the groups have identical (or in any case very close) $\mathrm{J}_{\mathrm{C}-\mathrm{H}}$ coupling constants, which is rarely verified.

The ${ }^{13} \mathrm{C}$-INEPT method has already been discussed in the CEISAM "Chemistry and Interdisciplinarity, Synthesis, Analysis, Modeling" laboratory in the EBSI team under these fundamental and application aspects [7]. The application with the resulting cocoa butter was carried out in collaboration with the NMR specialists of the EBSI team. The ${ }^{13} \mathrm{C}$ NMR experiments were carried out on the $500 \mathrm{MHz}$ Bruker Avance III spectrometer equipped with a ${ }^{13} \mathrm{C} /{ }^{1} \mathrm{H}$ dual cryo probe with ${ }^{2} \mathrm{H}$ lock. All the experiments were carried out at a temperature of 293 $\mathrm{K}$ and without rotating the tubes.

The ${ }^{13} \mathrm{C}$ NMR isotopic analysis of the glycerol of the triglycerides of cocoa butter was also carried out using a ${ }^{13} \mathrm{C}$ acquisition sequence, decoupled ${ }^{1} \mathrm{H}$ consisting of a recovery time followed by the application of an excitation pulse of which 1 The rocking angle is equal to $90^{\circ}$ and decoupling ${ }^{1} \mathrm{H}$ during the collection of the FID only (zgig sequence). This sequence will serve as a reference to calibrate the results obtained with the ${ }^{13} \mathrm{C}$-INEPT sequence. The parameters used for this measurement are as follows:

- Signal acquisition time (AQ): $1 \mathrm{~s}$ and $T_{1_{\max }}=3.6 \mathrm{~s}$

- Time between two passages (D1): $42 \mathrm{~s}\left(\mathrm{TR}=\mathrm{D} 1+\mathrm{AQ}=43 \mathrm{~s}>10 \mathrm{~T} 1_{\max }\right)$

- Number of passages (NS): 72 with a $\mathrm{S} / \mathrm{N}$ ratio $\geq 500$

The duration of the isotopic analysis of the glycerol of the triglycerides of cocoa butter being relatively long (55 min per spectrum), a polarization transfer method making it possible to increase the sensitivity and therefore to reduce the analysis time for the same S/B was used ( $12 \mathrm{~min}$ per spectrum). The transfer method that was chosen is a refocused INEPT (Insensitive Nuclei Enhancement by Polarization Transfer) in which the $180^{\circ}$ inversion and refocusing pulses are adiabatic pulses [8] (Figure 1). The parameters of this sequence and more particularly the delays of the two spin echoes were optimized so as to obtain the same $\delta^{13} \mathrm{C}(\%)$ as those obtained by the zgig sequence on the 2 sites relating to the glycerol of the triglycerides of cocoa butter. The optimized parameters for this refocused INEPT-sequence are as follows:

- Signal acquisition time (AQ): $1 \mathrm{~s}$ and $T_{1_{\max }}=2.8 \mathrm{~s}$

- Time between two passages (D1): $24 \mathrm{~s}\left(\mathrm{TR}=\mathrm{D} 1+\mathrm{AQ}=25 \mathrm{~s} \geq 8 T_{1_{\max }}\right)$

- Times $t_{1}=2.7 \mathrm{msec}$ and $t_{2}=1.405 \mathrm{msec}-$ Number of passages (NS): 24 with 


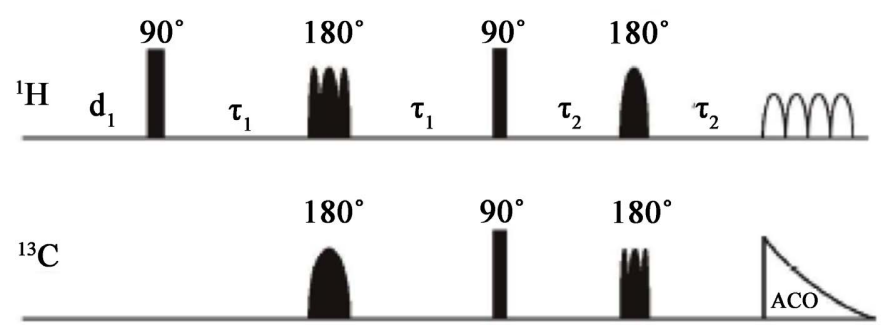

Figure $1 .{ }^{13} \mathrm{C}$-INEPT-refocused sequence in which the $180^{\circ}$ inversion and refocus are adiabatic pulses.

a $\mathrm{S} / \mathrm{N}$ ratio $\geq 800$.

For the two sequences, 5 spectra were carried out. However, all the spectra carried out on the cocoa butter samples were obtained with the refocused INEPT-sequence, only on one of the samples of the series the zgig sequence was operated in order to ensure that we always obtained the same results. The acquired ${ }^{13} \mathrm{C}$ NMR spectra were subsequently processed with a decreasing exponential type apodization function using a line broadening factor (lb) of $1.5 \mathrm{~Hz}$. The baseline correction was made by part with a polynomial of degree 5 . The area of the different lines present on the NMR- ${ }^{13} \mathrm{C}$ spectra was determined using the Perch software (University of Kuopio, Finland). The different components of the lines corresponding to the carbon sites relating to glycerol and to the fatty acids of the triglycerides of cocoa butter were deconvoluted by Lorentzian lines whose chemical shifts, the width at mid-height and the amplitude of the peaks were adjusted. In the case of the measurements obtained with the zgig sequence our results are perfectly validated, in the case of the INEPT-refocused sequence, by the sequence itself the areas of the signals are not only proportional to the number of ${ }^{13} \mathrm{C}$ nuclei [9]. Thus, an average corrective factor established on the results of the 9 samples measured with the zgig sequence was applied to the areas obtained with the INEPT-refocused sequence.

\section{Results and Discussion}

\subsection{Application to Glycerol and Fatty Acids of the Triglycerides of Cocoa Butter}

There are two types of information that can be obtained from the ${ }^{13} \mathrm{C}-\mathrm{NMR}$ spectra acquired with the zgig and refocused INEPT sequences: on the one hand, information on the $\delta^{13} \mathrm{C}(\% 0)$ isotopic deviations of the two observable sites due to the symmetry of the glycerol (C-1, C-3 and C-2) and on the other hand information on the fatty acid composition of triglycerides in cocoa butter. Indeed, the NMR- ${ }^{13} \mathrm{C}$ spectrum of cocoa butter is divided into 4 regions (Figure 2):

- The carbonyl region from 165 to $180 \mathrm{ppm}$

- The region of olefinic carbons from 120 to $140 \mathrm{ppm}$

- The glycerol region from 55 to $74 \mathrm{ppm}$

- The region of aliphatic carbons from 10 to 40 ppm 


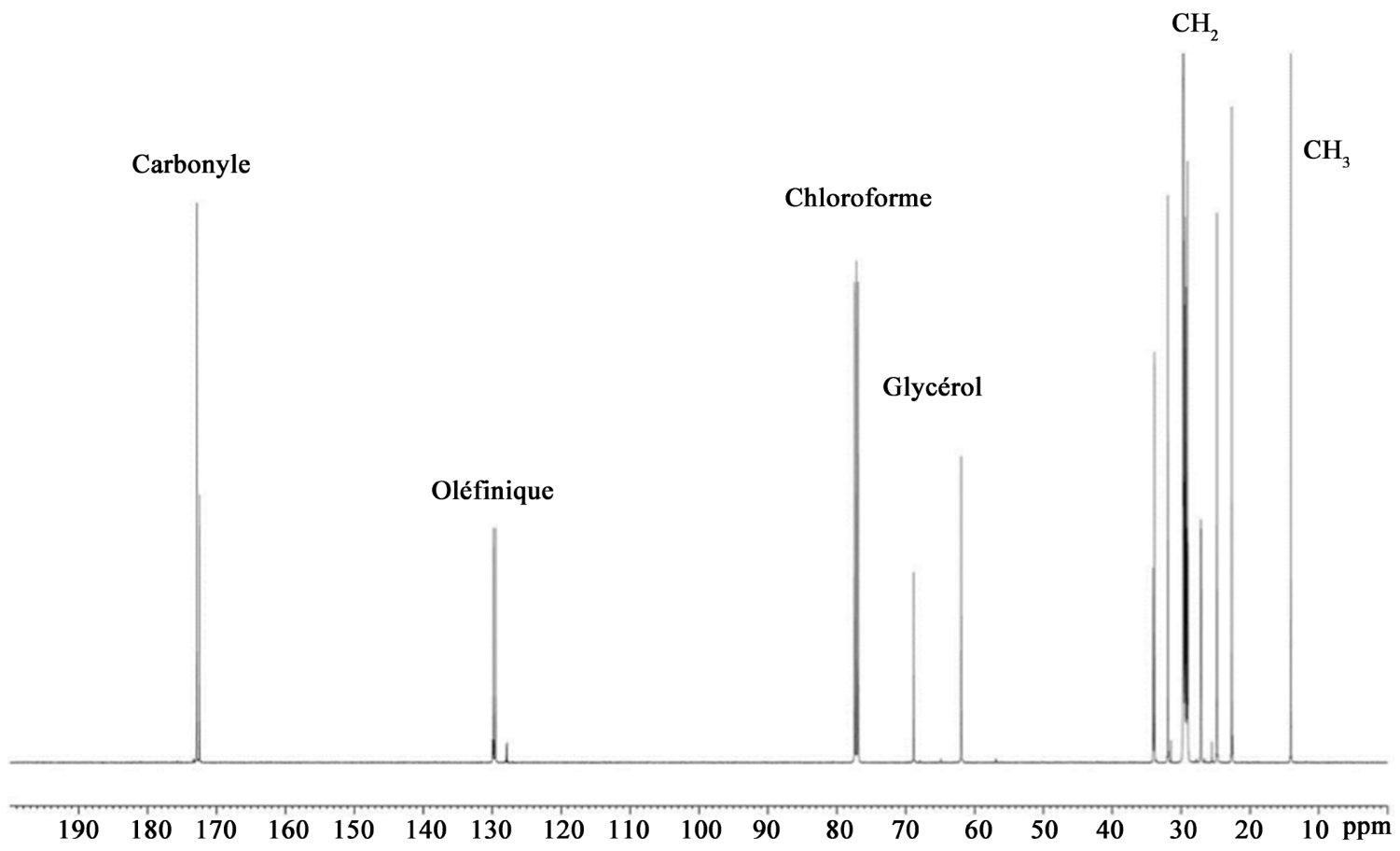

Figure 2. ${ }^{13} \mathrm{C}$ NMR spectrum (zgig sequence) of cocoa butter in $\mathrm{CDCl}_{3}$ on the $500 \mathrm{MHz}$ spectrometer.

Each of these regions can provide us with information of a different nature and/or validate the results obtained on other areas of the spectrum, a complete allocation of each of the regions was therefore carried out according to the literature (Figure 3). The number following the name of the esterified fatty acid chain corresponds to the carbon number according to the classical nomenclature used to describe fatty acids. As a reminder, the general chemical formula of triglycerides is shown in Figure 4. The carbon chains R1, R2 and R3 are fatty acids. The three fatty acids are not necessarily the same. The position on the glycerol backbone of the fatty acid chains is designated by the numbering position 1, 2 and 3. In triglycerides, the fatty acid chains can have 4 to 32 carbon atoms, but those of 16 and 18 atoms are the most common lengths. Triglycerides can be saturated, monounsaturated, or polyunsaturated. The fatty acids mainly contained in cocoa butter are: oleic, palmitic and stearic acid.

In the case of the measurements obtained with the zgig sequence our results are perfectly validated, in the case of the refocused INEPT-sequence, by the sequence itself the areas of the signals are not only proportional to the number of ${ }^{13} \mathrm{C}$ nuclei [9]. Thus, an average corrective factor established on the results of the 9 samples measured with the zgig sequence was applied to the areas obtained with the refocused INEPT-sequence. The chemical compositions obtained from the cocoa butters, as well as the isotopic deviations determined on the glycerol contained in the cocoa butters are given in Table 1.

\subsection{Statistical Treatment of the Data Obtained}

Analysis of these results shows that the chemical fatty acid composition of cocoa 

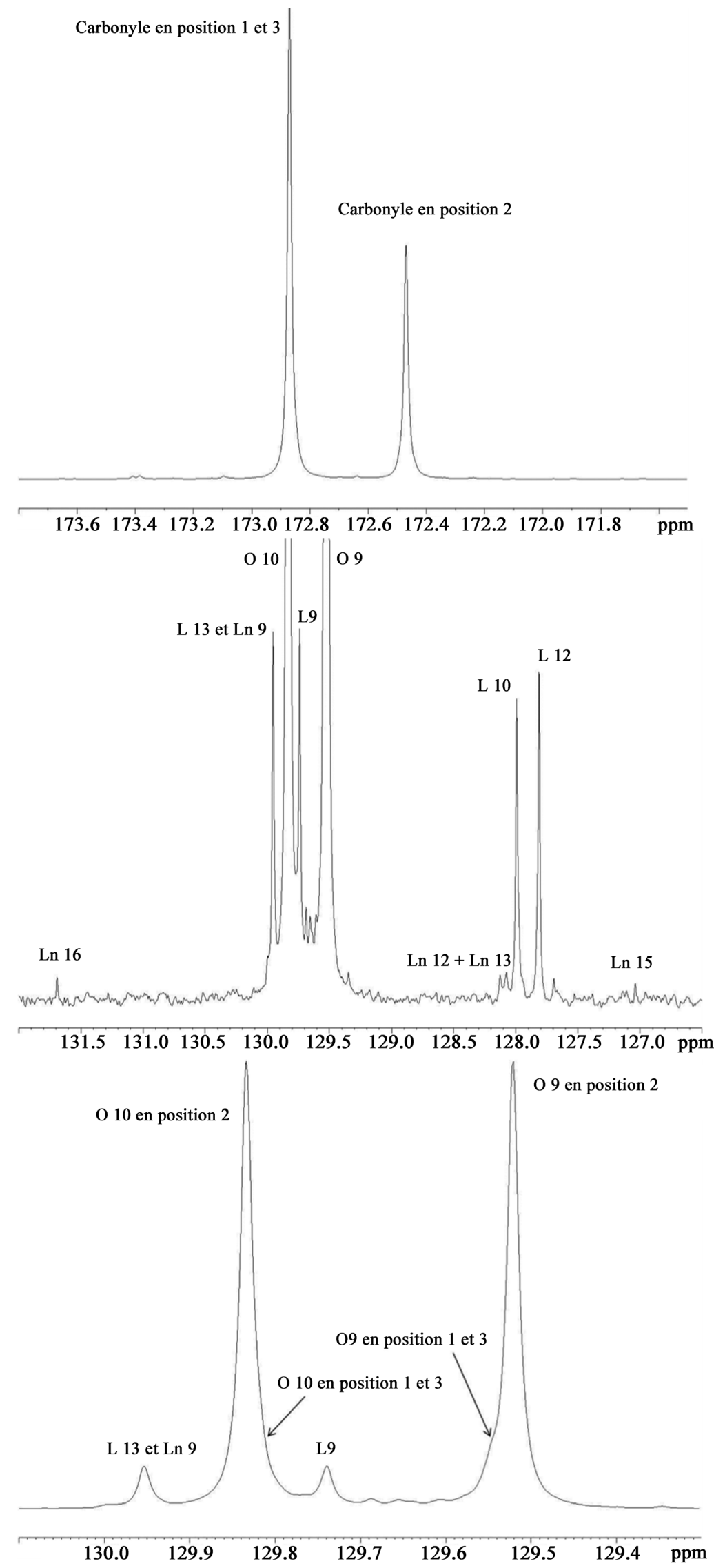


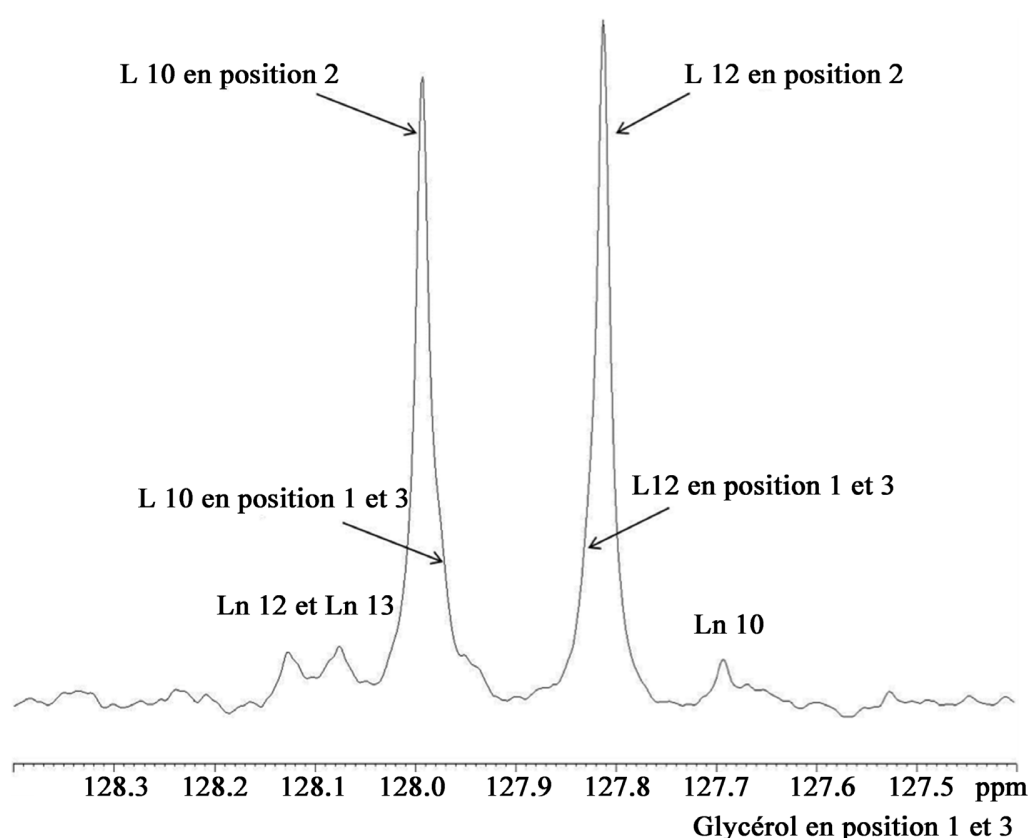

Glycérol en position 2

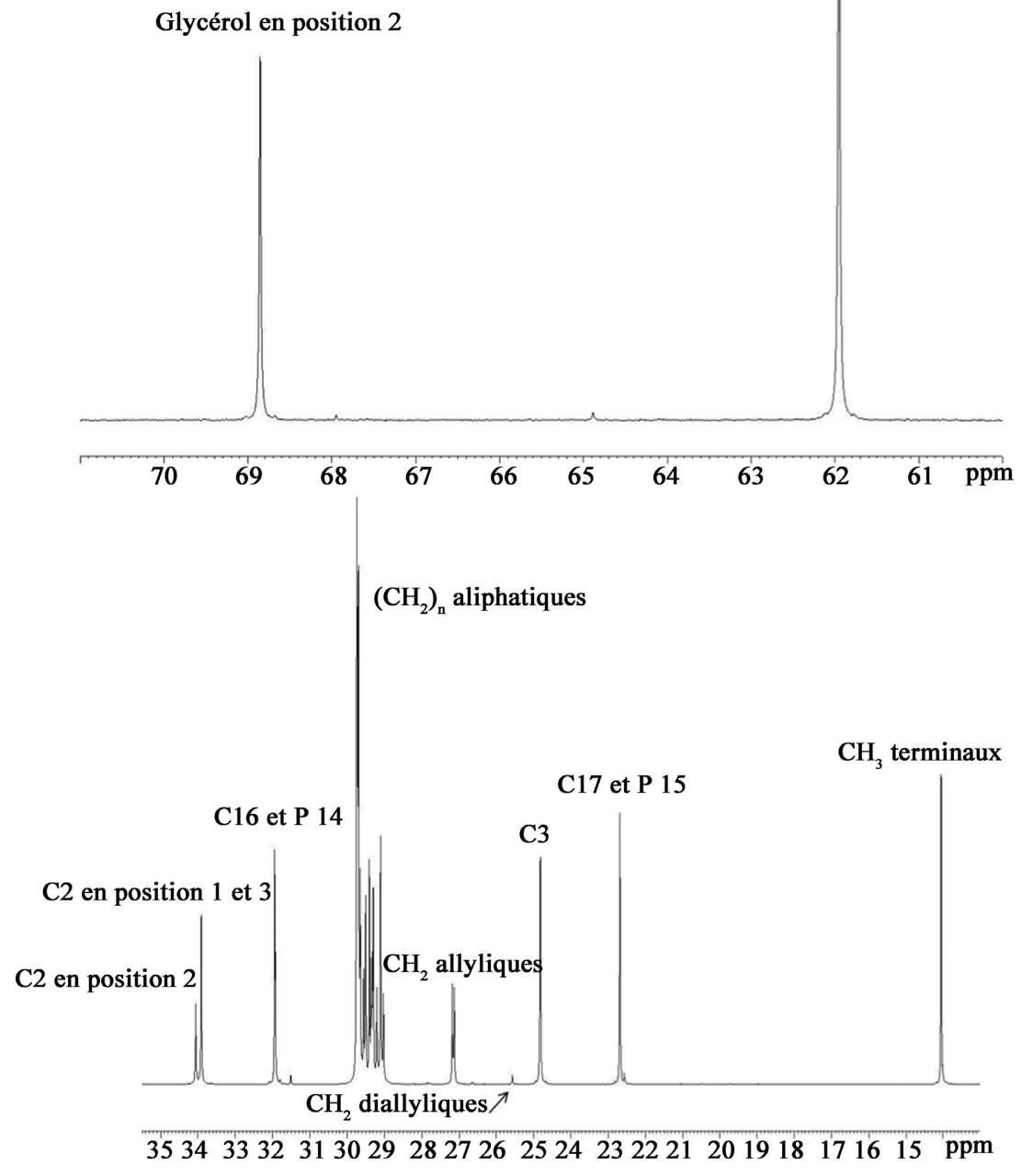




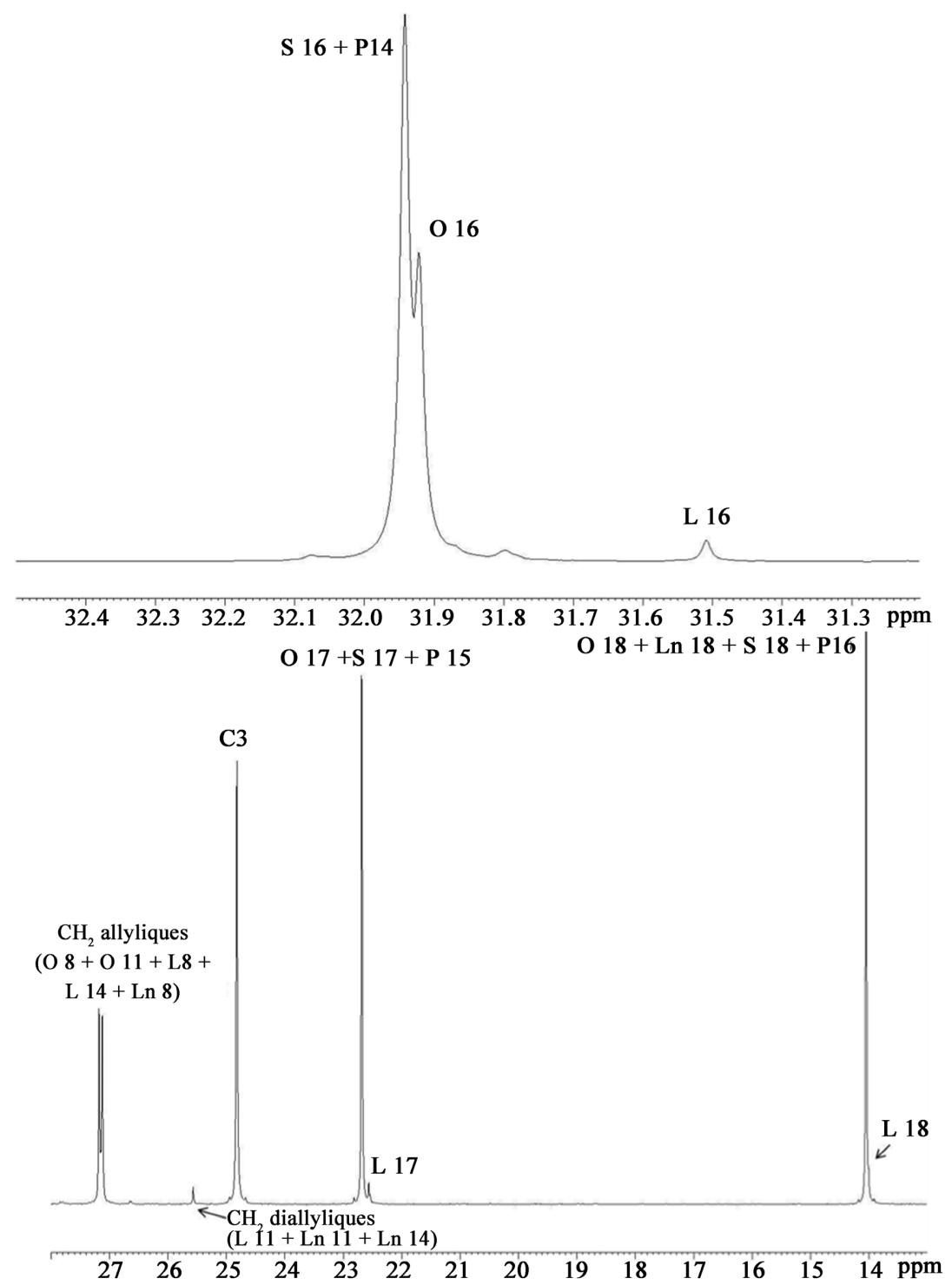

Figure 3. Assignment of the different areas of the ${ }^{13} \mathrm{C}$ NMR spectrum of cocoa butter. The signals corresponding to the chains of fatty acids esterified at position 1, 3 or 2 of glycerol are indicated as follows: L (Linoleyl), Ln (Linolenyl), O (Oleyl), P (Palmityl) and S (Stearyl), the position of the esterification of the fatty acid chain on glycerol is indicated.

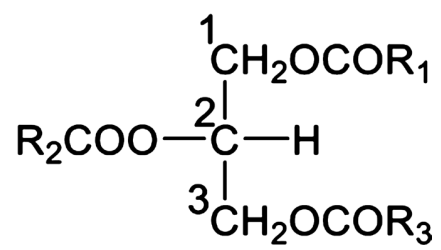

Figure 4. General chemical formula of triglycerides.

butter is predominantly made up of saturated fatty acids, followed by the monounsaturated ones. Thus, we have nearly $63 \%$ to $68 \%$ of saturated fatty acids composed mainly of stearic acid and palmitic acid, while monounsaturated fatty acids (oleic acid) represent 30\% to 32\%. Polyunsaturated acids represent less 
Table 1. Chemical composition of fatty acids in cocoa butter and the $\delta^{13} \mathrm{C}-2$ and $\delta^{13} \mathrm{C}-1-3$ isotopic signatures of the glycerol contained in cocoa butter.

\begin{tabular}{|c|c|c|c|c|c|c|c|c|}
\hline \multirow{2}{*}{ Origines } & \multicolumn{2}{|c|}{$\begin{array}{c}\text { \% du linoléique à partir } \\
\text { du C16 }\end{array}$} & \multicolumn{2}{|c|}{$\begin{array}{c}\% \text { des oléiques } 1-3= \\
010\end{array}$} & \multicolumn{2}{|c|}{$\%$ des oléiques $2=010$} & \multicolumn{2}{|c|}{$\begin{array}{c}\text { \% des linoléiques } 1-3= \\
\text { L10 }\end{array}$} \\
\hline & Mean & $\begin{array}{l}\text { Standard } \\
\text { deviation }\end{array}$ & Mean & $\begin{array}{l}\text { Standard } \\
\text { deviation }\end{array}$ & Mean & $\begin{array}{l}\text { Standard } \\
\text { deviation }\end{array}$ & Mean & $\begin{array}{l}\text { Standard } \\
\text { deviation }\end{array}$ \\
\hline Abengourou (21) & 2.46 & 0.03 & 9.44 & 0.35 & 90.69 & 0.32 & 14.53 & 1.00 \\
\hline Aboisso (21) & 2.58 & 0.03 & 6.61 & 0.57 & 93.28 & 0.52 & 8.03 & 1.10 \\
\hline Agboville (21) & 2.44 & 0.02 & 5.56 & 0.12 & 94.23 & 0.11 & 10.32 & 0.96 \\
\hline Alepé (21) & 2.62 & 0.02 & 10.39 & 0.77 & 89.82 & 0.70 & 10.34 & 1.18 \\
\hline Azaguié (21) & 2.37 & 0.01 & 7.55 & 0.48 & 92.42 & 0.44 & 11.65 & 0.89 \\
\hline Biankouma (21) & 2.40 & 0.01 & 6.93 & 0.37 & 92.99 & 0.34 & 1124 & 1.38 \\
\hline Bolivie (1) & 2.12 & 0.01 & 8.59 & 1.35 & 91.47 & 1.24 & 1672 & 0.84 \\
\hline Brésil (2) & 3.23 & 0.01 & 11.52 & 1.55 & 88.79 & 1.41 & 12.80 & 1.27 \\
\hline Cameroun (3) & 2.23 & 0.01 & 16.18 & 0.10 & 84.54 & 0.09 & 23.23 & 2.20 \\
\hline Colombie (4) & 3.29 & 0.03 & 8.16 & 0.20 & 91.86 & 0.19 & 11.70 & 0.18 \\
\hline Costa Rica (5) & 2.88 & 0.02 & 9.62 & 0.93 & 90.52 & 0.85 & 11.82 & 1.11 \\
\hline Dabou (21) & 2.82 & 0.03 & 4.27 & 0.28 & 95.41 & 0.26 & 8.73 & 0.46 \\
\hline Daloa (21) & 2.96 & 0.03 & 9.93 & 0.43 & 90.24 & 0.39 & 12.50 & 0.63 \\
\hline Danané (21) & 2.53 & 0.03 & 6.33 & 0.26 & 93.53 & 0.24 & 8.50 & 1.04 \\
\hline Dimbokro (21) & 2.46 & 0.02 & 7.49 & 2.40 & 92.48 & 2.19 & 14.68 & 1.32 \\
\hline Divo (21) & 2.44 & 0.01 & 6.48 & 0.27 & 93.39 & 0.25 & 11.23 & 2.34 \\
\hline Douroubé (21) & 2.60 & 0.01 & 10.41 & 0.41 & 89.81 & 0.37 & 13.45 & 1.53 \\
\hline Duékoué (21) & 2.57 & 0.02 & 6.37 & 0.36 & 93.50 & 0.33 & 12.61 & 1.34 \\
\hline Equateur (6) & 2.40 & 0.02 & 9.04 & 0.38 & 91.06 & 0.35 & 10.36 & 0.44 \\
\hline Gabon (7) & 3.08 & 0.02 & 12.55 & 0.76 & 87.86 & 0.70 & 13.01 & 1.39 \\
\hline Ghana (8) & 2.66 & 0.01 & 11.31 & 1.60 & 88.99 & 1.46 & 13.72 & 1.56 \\
\hline Guatemala (9) & 2.17 & 0.03 & 15.12 & 1.39 & 85.51 & 1.27 & 23.03 & 1.16 \\
\hline Gueyo (21) & 2.63 & 0.02 & 6.51 & 1.56 & 93.37 & 1.42 & 8.49 & 1.66 \\
\hline Guiglo (21) & 2.61 & 0.03 & 11.66 & 1.41 & 88.66 & 1.29 & 11.38 & 1.46 \\
\hline Indonésie (10) & 2.57 & 0.04 & 9.06 & 1.27 & 91.05 & 1.16 & 13.84 & 1.25 \\
\hline Jamaïque (11) & 3.15 & 0.03 & 1527 & 1.17 & 85.38 & 1.07 & 14.14 & 0.88 \\
\hline Kouibly (21) & 2.57 & 0.03 & 5.83 & 0.21 & 93.99 & 0.19 & 11.28 & 2.05 \\
\hline Madagascar (12) & 2.07 & 0.02 & 7.70 & 0.27 & 92.28 & 0.25 & 16.78 & 1.42 \\
\hline Malaisie (13) & 2.65 & 0.02 & 9.11 & 1.71 & 90.99 & 1.56 & 10.59 & 1.07 \\
\hline Man (21) & 2.93 & 0.03 & 9.33 & 0.35 & 90.79 & 0.32 & 10.97 & 1.18 \\
\hline Martinique (14) & 2.66 & 0.02 & 6.31 & 0.25 & 93.55 & 0.23 & 13.83 & 1.60 \\
\hline
\end{tabular}




\section{Continued}

\begin{tabular}{|c|c|c|c|c|c|c|c|c|}
\hline Oumé (21) & 2.59 & 0.03 & 7.58 & 0.37 & 92.39 & 0.34 & 15.41 & 1.20 \\
\hline Pérou (15) & 2.53 & 0.03 & 6.39 & 0.27 & 93.48 & 0.25 & 14.57 & 3.93 \\
\hline PNG (16) & 2.31 & 0.01 & 3.97 & 0.25 & 95.68 & 0.23 & 1218 & 1.14 \\
\hline REP. Dominicaine (17) & 3.13 & 0.02 & 16.73 & 0.56 & 84.04 & 0.51 & 19.39 & 0.64 \\
\hline San Pedro (21) & 2.70 & 0.01 & 9.47 & 0.26 & 90.67 & 0.23 & 50.39 & 0.29 \\
\hline Soubré (21) & 2.50 & 0.03 & 8.02 & 0.27 & 91.99 & 0.25 & 13.19 & 0.83 \\
\hline Trinidad (18) & 2.68 & 0.03 & 4.63 & 0.30 & 95.08 & 0.28 & 12.59 & 1.57 \\
\hline Venezuela (19) & 2.73 & 0.03 & 13.20 & 0.15 & 87.26 & 0.14 & 20.75 & 1.16 \\
\hline Vietnam (20) & 2.27 & 0.02 & 6.54 & 0.13 & 93.34 & 0.12 & 9.49 & 1.20 \\
\hline Yakro (21) & 1.99 & 0.02 & 10.43 & 0.22 & 89.79 & 0.20 & 17.61 & 4.18 \\
\hline \multirow{2}{*}{ Origines } & \multicolumn{2}{|c|}{$\begin{array}{c}\% \text { des linoléiques } 2= \\
\text { L10 }\end{array}$} & \multicolumn{2}{|c|}{$\begin{array}{c}\text { \% Insaturés } \\
(\mathrm{O}+\mathrm{L}+\mathrm{Ln})\end{array}$} & \multicolumn{2}{|c|}{$\%$ des polyinsaturés } & \multicolumn{2}{|c|}{ \% linolénique Ln16 } \\
\hline & Mean & $\begin{array}{l}\text { Standard } \\
\text { deviation }\end{array}$ & Mean & $\begin{array}{l}\text { Standard } \\
\text { deviation }\end{array}$ & Mean & $\begin{array}{l}\text { Standard } \\
\text { deviation }\end{array}$ & Mean & $\begin{array}{l}\text { Standard } \\
\text { deviation }\end{array}$ \\
\hline Abengourou & 95.22 & 1.18 & 33.91 & 0.02 & 2.67 & 0.03 & 0.15 & 0.03 \\
\hline Aboisso & 102.93 & 1.30 & 34.45 & 0.03 & 2.88 & 0.02 & 0.15 & 0.03 \\
\hline Agboville & 100.21 & 1.14 & 33.37 & 0.03 & 2.78 & 0.18 & 0.14 & 0.03 \\
\hline Alepé & 100.18 & 1.40 & 33.47 & 0.02 & 2.83 & 0.02 & 0.15 & 0.02 \\
\hline Azaguié & 98.64 & 1.05 & 33.48 & 0.01 & 2.58 & 0.03 & 0.15 & 0.02 \\
\hline Biankouma & 99.12 & 1.64 & 33.83 & 0.03 & 2.63 & 0.01 & 0.14 & 0.03 \\
\hline Bolivie & 92.62 & 0.99 & 34.58 & 0.02 & 2.47 & 0.02 & 0.17 & 0.03 \\
\hline Brésil & 97.27 & 1.50 & 35.48 & 0.01 & 3.49 & 0.02 & 0.18 & 0.03 \\
\hline Cameroun & 84.91 & 2.60 & 33.15 & 0.01 & 2.52 & 0.03 & 0.12 & 0.02 \\
\hline Colombie & 98.58 & 0.22 & 34.09 & 0.01 & 3.51 & 0.03 & 0.18 & 0.02 \\
\hline Costa Rica & 98.43 & 1.31 & 35.29 & 0.01 & 3.15 & 0.04 & 0.20 & 0.03 \\
\hline Dabou & 102.10 & 0.54 & 33.56 & 0.02 & 3.05 & 0.01 & 0.17 & 0.02 \\
\hline Daloa & 97.62 & 0.75 & 35.25 & 0.03 & 3.14 & 0.02 & 0.18 & 0.02 \\
\hline Danané & 102.36 & 1.23 & 33.77 & 0.02 & 2.99 & 0.34 & 0.14 & 0.02 \\
\hline Dimbokro & 95.04 & 1.57 & 33.01 & 0.02 & 2.62 & 0.02 & 0.12 & 002 \\
\hline Divo & 99.14 & 2.78 & 33.57 & 0.02 & 2.68 & 0.03 & 0.14 & 002 \\
\hline Douroubé & 96.50 & 1.81 & 33.52 & 0.03 & 2.75 & 0.01 & 0.12 & 002 \\
\hline Duékoué & 97.50 & 1.59 & 33.50 & 0.03 & 2.86 & 0.12 & 0.18 & 003 \\
\hline Equateur & 100.16 & 0.52 & 33.96 & 0.02 & 2.71 & 0.02 & 0.17 & 002 \\
\hline Gabon & 97.02 & 1.64 & 36.14 & 0.03 & 3.32 & 0.03 & 0.16 & 004 \\
\hline Ghana & 96.18 & 1.85 & 33.75 & 0.01 & 2.91 & 0.03 & 0.15 & 001 \\
\hline
\end{tabular}




\section{Continued}

\begin{tabular}{|c|c|c|c|c|c|c|c|c|}
\hline Guatemala & 85.15 & 1.37 & 33.30 & 001 & 2.69 & 0.05 & 0.08 & 002 \\
\hline Gueyo & 102.37 & 1.96 & 34.11 & 0.02 & 2.82 & 0.04 & 0.18 & 003 \\
\hline Guiglo & 98.95 & 1.73 & 33.90 & 0.07 & 2.77 & 0.03 & 0.14 & 004 \\
\hline Indonésie & 96.04 & 1.48 & 34.85 & 0.01 & 2.88 & 0.02 & 0.19 & 001 \\
\hline Jamaïque & 95.68 & 1.04 & 36.06 & 0.01 & 3.42 & 003 & 0.18 & 003 \\
\hline Kouibly & 99.08 & 2.43 & 33.85 & 0.02 & 2.81 & 0.03 & 0.14 & 001 \\
\hline Madagascar & 92.56 & 1.68 & 34.15 & 0.01 & 2.43 & 0.03 & 0.19 & 003 \\
\hline Malaisie & 99.88 & 1.26 & 34.00 & 0.02 & 2.95 & 0.01 & 0.20 & 001 \\
\hline $\operatorname{Man}(\mathrm{CI})$ & 99.45 & 1.40 & 34.81 & 0.03 & 3.13 & 0.05 & 0.17 & 002 \\
\hline Martinique & 96.05 & 1.90 & 34.33 & 0.02 & 2.89 & 0.04 & 0.18 & 002 \\
\hline Oumé & 94.18 & 1.42 & 33.48 & 0.04 & 2.78 & 0.02 & 0.16 & 003 \\
\hline Pérou & 95.17 & 4.65 & 33.04 & 0.02 & 2.75 & 0.02 & 0.14 & 000 \\
\hline PNG & 98.00 & 1.35 & 33.77 & 0.65 & 2.61 & 0.04 & 0.17 & 004 \\
\hline REP. Dominicaine & 89.46 & 0.76 & 36.45 & 0.02 & 3.40 & 0.02 & 0.18 & 003 \\
\hline San Pedro & 52.73 & 0.97 & 34.15 & 0.03 & 2.90 & 0.04 & 0.17 & 002 \\
\hline Soubré & 96.80 & 0.98 & 33.26 & 0.02 & 2.78 & 0.04 & 0.18 & 002 \\
\hline Trinidad & 97.53 & 1.87 & 33.58 & 0.02 & 2.98 & 0.02 & 0.17 & 003 \\
\hline Venezuela & 87.85 & 1.38 & 34.72 & 0.03 & 3.05 & 0.04 & 0.21 & 001 \\
\hline Vietnam & 101.19 & 1.42 & 33.82 & 0.02 & 2.61 & 0.04 & 0.16 & 003 \\
\hline Yakro & 91.57 & 4.95 & 32.51 & 0.03 & 2.32 & 0.01 & 0.12 & 002 \\
\hline \multirow[b]{2}{*}{ Origines } & \multicolumn{2}{|c|}{$\%$ monoinsaturés } & \multicolumn{2}{|c|}{$\%$ des saturés $(\mathrm{P}+\mathrm{S})$} & \multicolumn{2}{|c|}{$\mathrm{C}-2$} & \multicolumn{2}{|c|}{ C-1 et C-3 } \\
\hline & Mean & $\begin{array}{l}\text { Standard } \\
\text { deviation }\end{array}$ & Mean & $\begin{array}{l}\text { Standard } \\
\text { deviation }\end{array}$ & $\begin{array}{c}\delta \text { i mean } \\
(\%)\end{array}$ & $\begin{array}{l}\text { Standard } \\
\text { deviation }\end{array}$ & $\begin{array}{c}\delta \text { i mean } \\
(\%)\end{array}$ & $\begin{array}{l}\text { Standard } \\
\text { deviation }\end{array}$ \\
\hline Abengourou & 31.24 & 0.03 & 66.10 & 0.02 & -14.62 & 1.35 & -39.55 & 0.67 \\
\hline Aboisso & 31.57 & 0.03 & 65.54 & 0.03 & -13.97 & 0.35 & -39.81 & 0.17 \\
\hline Agboville & 30.59 & 0.20 & 66.66 & 0.03 & -15.52 & 0.31 & -40.18 & 0.15 \\
\hline Alepé & 30.64 & 0.04 & 66.56 & 0.02 & -16.65 & 0.80 & -38.85 & 0.40 \\
\hline Azaguié & 30.90 & 0.02 & 66.55 & 0.01 & -13.07 & 0.84 & -38.67 & 0.42 \\
\hline Biankouma & 31.20 & 0.03 & 66.18 & 0.03 & -16.36 & 0.66 & -39.19 & 0.33 \\
\hline Bolivie & 32.11 & 0.03 & 65.40 & 0.02 & -16.29 & 0.73 & -40.45 & 0.36 \\
\hline Brésil & 31.99 & 0.04 & 64.47 & 0.02 & -14.32 & 1.02 & -39.05 & 0.51 \\
\hline Cameroun & 30.63 & 0.02 & 66.89 & 0.01 & -18.19 & 0.41 & -39.23 & 0.20 \\
\hline Colombie & 30.58 & 0.03 & 65.91 & 0.01 & -11.14 & 0.57 & -39.59 & 0.28 \\
\hline Costa Rica & 32.14 & 0.04 & 64.66 & 0.01 & -12.76 & 0.70 & -39.80 & 0.35 \\
\hline Dabou & 30.51 & 0.03 & 66.46 & 0.02 & -14.49 & 0.49 & -40.81 & 0.25 \\
\hline
\end{tabular}




\section{Continued}

\begin{tabular}{|c|c|c|c|c|c|c|c|c|}
\hline Daloa & 32.11 & 0.01 & 64.70 & 0.03 & -15.70 & 0.89 & -40.07 & 0.44 \\
\hline Danané & 30.78 & 0.34 & 66.25 & 0.02 & -15.25 & 0.69 & -39.64 & 0.35 \\
\hline Dimbokro & 30.39 & 0.01 & 67.04 & 0.02 & -16.34 & 1.16 & -39.18 & 0.58 \\
\hline Divo & 30.88 & 0.02 & 66.46 & 0.02 & -14.13 & 0.73 & -39.91 & 0.36 \\
\hline Douroubé & 30.77 & 0.03 & 66.51 & 0.03 & -14.84 & 1.06 & -40.41 & 0.53 \\
\hline Duékoué & 30.65 & 0.11 & 66.53 & 0.03 & -16.85 & 1.31 & -38.09 & 0.66 \\
\hline Equateur & 31.25 & 0.02 & 66.05 & 0.02 & -15.39 & 1.00 & -38.68 & 0.50 \\
\hline Gabon & 32.82 & 0.03 & 63.78 & 0.03 & -17.92 & 0.69 & -38.44 & 0.35 \\
\hline Ghana & 30.83 & 0.03 & 66.27 & 0.01 & -14.16 & 0.88 & -40.05 & 0.44 \\
\hline Guatemala & 30.62 & 0.05 & 66.73 & 0.01 & -15.77 & 0.75 & -39.54 & 0.38 \\
\hline Gueyo & 31.29 & 0.04 & 65.89 & 0.02 & -15.46 & 1.08 & -39.55 & 0.54 \\
\hline Guiglo & 31.13 & 0.09 & 66.11 & 0.07 & -17.22 & 1.38 & -39.36 & 0.69 \\
\hline Indonésie & 31.97 & 0.02 & 65.12 & 0.01 & -15.05 & 0.22 & -39.32 & 0.11 \\
\hline Jamaïque & 32.64 & 0.03 & 63.87 & 0.01 & -13.56 & 1.22 & -37.87 & 0.61 \\
\hline Kouibly & 31.05 & 0.04 & 66.16 & 0.02 & -16.72 & 0.95 & -39.77 & 0.47 \\
\hline Madagascar & 31.72 & 0.03 & 65.85 & 0.01 & -13.66 & 0.34 & -38.38 & 0.17 \\
\hline Malaisie & 31.05 & 0.03 & 66.01 & 0.02 & -15.11 & 0.50 & -39.59 & 0.25 \\
\hline $\operatorname{Man}(\mathrm{CI})$ & 31.68 & 0.03 & 65.17 & 0.03 & -13.97 & 0.58 & -39.72 & 0.29 \\
\hline Martinique & 31.43 & 0.04 & 65.67 & 0.02 & -14.04 & 0.71 & -38.80 & 0.36 \\
\hline Oumé & 30.70 & 0.05 & 6655 & 005 & -14.74 & 0.15 & -38.03 & 0.08 \\
\hline Pérou & 30.29 & 0.03 & 6700 & 002 & -13.16 & 0.80 & -39.47 & 0.40 \\
\hline PNG & 31.16 & 0.63 & 6625 & 067 & -11.59 & 0.82 & -40.55 & 0.41 \\
\hline REP. Dominicaine & 33.05 & 0.02 & 6346 & 002 & -15.98 & 1.24 & -40.66 & 0.62 \\
\hline San Pedro & 31.25 & 0.02 & 6585 & 003 & -18.24 & 0.54 & -384.0 & 0.27 \\
\hline Soubré & 30.48 & 0.03 & 6677 & 002 & -14.55 & 0.64 & -39.99 & 0.32 \\
\hline Trinidad & 30.60 & 0.02 & 6644 & 002 & -14.28 & 1.20 & -40.75 & 0.60 \\
\hline Venezuela & 31.67 & 0.04 & 6526 & 003 & -14.79 & 0.35 & -39.10 & 0.18 \\
\hline Vietnam & 31.21 & 0.05 & 6620 & 002 & -13.99 & 0.61 & -39.83 & 0.30 \\
\hline Yakro & 30.19 & 0.03 & 6756 & 003 & -14.99 & 0.84 & -39.53 & 0.42 \\
\hline
\end{tabular}

than $4 \%$. These results are consistent with those obtained by Anklam and Lipp (1998) [10].

Statistical processing was performed using $\mathrm{R}$ software [11]. The objective of this statistical treatment is to highlight the variations in the chemical composition of discriminating fatty acids on the one hand and the variations in the $\delta^{13} \mathrm{C}$ isotopic signature of glycerol on the other. Data from unsupervised univariate and multivariate analyzes will be used as appropriate. The unsupervised analysis 
allows to have a global view of all the data while the supervised analysis aims to bring out a reduced number of discriminating parameters while allowing the distinction between two or more groups. Principal component analysis was performed in order to materialize the discrimination between the samples from the 21 countries. So the samples from the Ivory Coast were all concentrated in one value and then the difference between these different values was insignificant. The numbers assigned to the countries in the tables represent are used in the ACP. Thus, the principal component analysis of Figure 5 makes it possible to highlight four (4) groups (clusters) with $81 \%$ discrimination. The parameters at the origin of this discrimination are the chemical compositions of fatty acid linoleic (L10), linolenic ( $\operatorname{Ln} 10)$, palmitic $(\mathrm{P})$ and unsaturated fatty acid (Oleic (O), Linoleic and Linolenic Ln) (Figure 6). Also the PCA in Figure 7 also highlighted (4) groups with $77.4 \%$ discrimination. The parameters responsible for this discrimination are the $\delta^{13} \mathrm{C}$ isotopic signatures of glycerol $\left(\delta^{13} \mathrm{C}-2, \delta^{13} \mathrm{C}-1-3\right)$ and the chemical compositions of saturated (Palmitic and Stearic) and monounsaturated fatty acids (Figure 8). Thus the chemical composition of fatty acids is linked to their biosynthesis in plants [12]. As a result, the varieties of cocoa trees can influence the discrimination observed on the different PCA. In fact, linoleic fatty acid is synthesized in abundance by gradual desaturation of oleic acid over a short period during the development of seeds or leaves [13]. The ${ }^{13} \mathrm{C}$ isotopic deviation from glycerol is also a very important parameter in discriminating geographic origin [14] [15]. Atmospheric $\mathrm{CO}_{2}$ is the main source of carbon used by plants during photosynthesis. The isotopic distribution of $\mathrm{CO}_{2}$ is homogeneous in the Earth's atmosphere, however it can be incorporated in two different ways by plants. So we have plants $\mathrm{C} 3$ and $\mathrm{C} 4$. In $\mathrm{C} 3$ plants, atmospheric $\mathrm{CO}_{2}$ first diffuses through the epidermis and stomata to the interior of the plant by a reversible process in which the fractionation is about $4 \%$. Then carboxylation by the enzyme RuBP further discriminates the heavy isotope, with a fractionation of

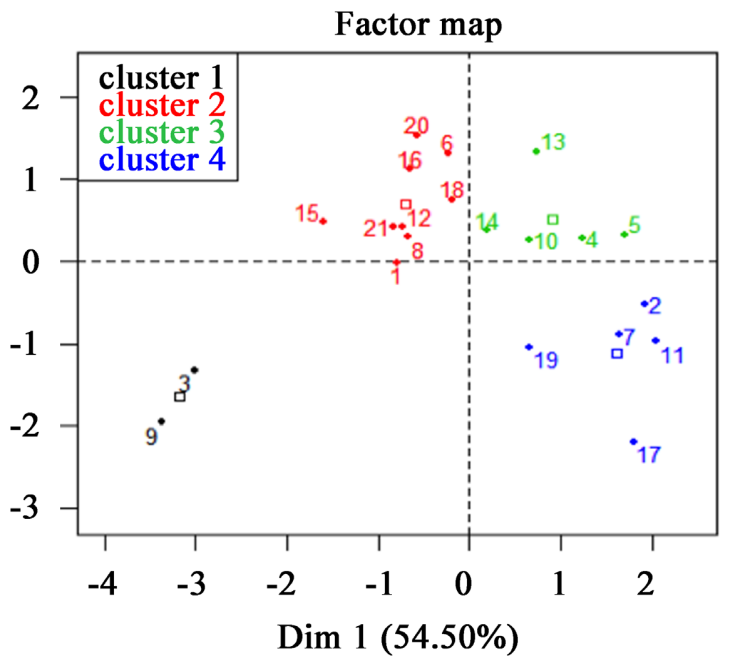

Figure 5. Main component analysis from the chemical composition of linoleic fatty acids (L10), linolenic (Ln10), palmital (P) and unsaturated (oleic (O), linoleic (L), linolenic (Ln)). 


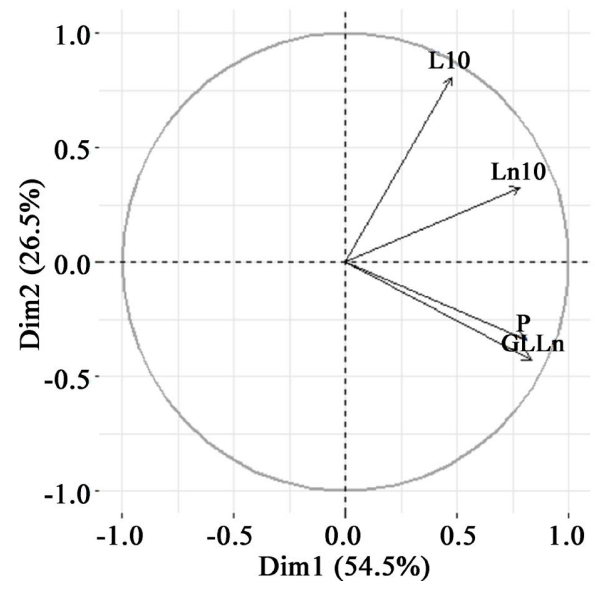

Figure 6. The parameters used for carrying out the main component analysis: the chemical composition of the linoleic fatty acids (L10), linolenic (Ln10), palmitic (P) and unsaturated acid (oleic $(\mathrm{O})$, linoleic (L), Linolenic ( $\mathrm{Ln})$ ).

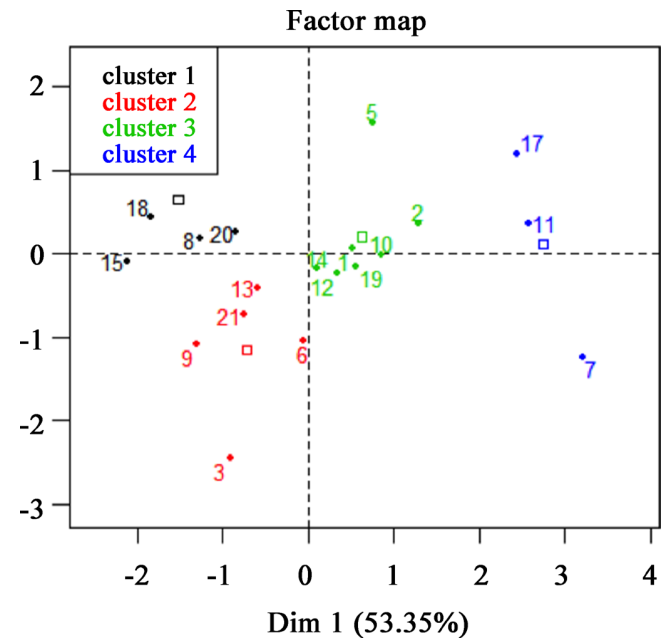

Figure 7. Main component analysis from the chemical composition of saturated fatty acids (palmitic, stearic: xp.s), monounsaturated (XM) $\beta$ cocoa butter and isotopic signatures $\delta^{13} \mathrm{C}-2$ and $\delta^{13} \mathrm{C}-1-3$ of glycerol.

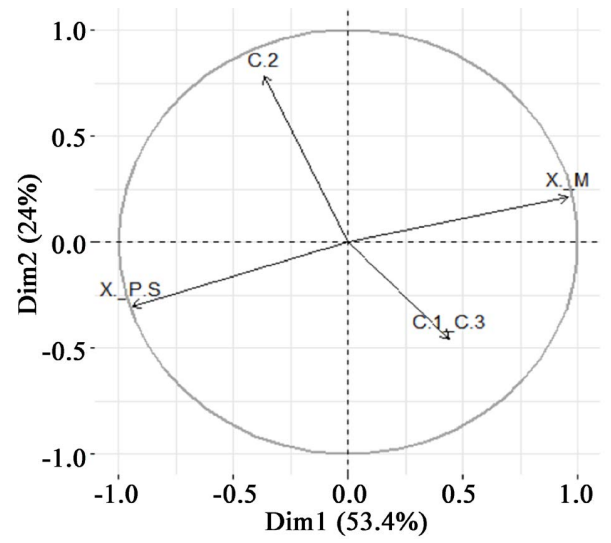

Figure 8. The parameters used for the realization of the main component analysis: the chemical composition of saturated fatty acids (palmitic, stearic: xp.s), monounsaturated $(\mathrm{XM})$ of cocoa butter and isotopic signatures $\delta^{13} \mathrm{C}-2$ and $\delta^{13} \mathrm{C}-1-3$ glycerol. 
about $29 \%$ [16]. If carbon uptake were limited only by the carboxylation process, fractionation would be $29 \%$ and C 3 plants would have an isotopic deviation of $-37 \%$. At the other extreme, if carbon uptake were limited only by diffusion processes, fractionation would be $4 \%$ and plants would have an isotopic signature of $-12 \%$. In reality, the total fractionation is between the fractionation due to diffusion and that due to carboxylation and the $\mathrm{C} 3$ plants have a between $-22 \%$ and $-30 \%$ [17] [18].

The isotopic composition in C4 plants differs substantially from that of C3 plants because the first carboxylating enzyme is much less discriminating for the heavy isotope [16]. After entering the plant by the same diffusion processes as for $\mathrm{C} 3$ plants, the $\mathrm{CO}_{2}$ is taken over by the PEP-carboxylase enzyme. This reaction is equivalent to a $5 \%$ - $6 \%$ fractionation. The products of this reaction are then taken over by the enzyme RuBP, which slightly discriminates against the heavy isotope of carbon [16]. Thus, the sudden fractionations during the diffusion and the action of the enzymes PEP-carboxylase and RuBP determine the isotopic composition of the $\mathrm{C} 4$ plants, which have a $\delta^{13} \mathrm{C}$ between $-10 \%$ and $-14 \%$ [19].

Therefore, isotopic fractionation at the carbon level is linked to the nature of the plant.

\section{Conclusion and Perspectives}

This study made it possible to determine the chemical composition of cocoa butter in fatty acids. Thus cocoa butter is mainly composed of saturated fatty acids and then come the monounsaturated ones. We have around $63 \%$ to $68 \%$ saturated fatty acids composed mainly of stearic acid and palmitic acid, while monounsaturated fatty acids (oleic acid) represent $30 \%$ to $32 \%$. Polyunsaturated acids represent less than $4 \%$. We were also able to measure the $\delta^{33} \mathrm{C}$ isotopic signature of the glycerol contained in cocoa butter. The statistical treatment of these different results made it possible to highlight a discrimination within the samples. However, a study of the different varieties of cocoa could better make it possible to bring out the most discriminating parameters while eliminating the varietal factor. Also taking into account seasonal parameters (precipitation, sunshine, atmospheric conditions, etc.) could allow a more in-depth study with a view to characterizing the geographical origin of the cocoa bean.

\section{Conflicts of Interest}

The authors declare no conflicts of interest regarding the publication of this paper.

\section{References}

[1] Hölzl, G. and Dörmann, P. (2007) Structure and Function of Glycoglycerolipids in Plants and Bacteria. Progress in Lipid Research, 46, 225-243. https://doi.org/10.1016/j.plipres.2007.05.001

[2] Ivanova, P., Milne, S., Byrne, M., Xiang, Y. and Brown, H. (2007) Glycerophospholipid Identification and Quantitation by Electrospray Ionization Mass Spectrometry, 
Methods in Enzymology, 432, 21-57. https://doi.org/10.1016/S0076-6879(07)32002-8

[3] Subramaniam, S., Fahy, E., Gupta, S., Manish, S., Byrnes, R., Cotter, D., Dinasarapu, A. and Maurya, M. (2011) Bioinformatics and Systems Biology of the Lipidome. Chemical Reviews, 111, 6452-6490. https://doi.org/10.1021/cr200295k

[4] Siri-Tarino, P., Sun, Q. and Krauss, R. (2010) Meta-Analysis of Prospective Cohort Studies Evaluating the Association of Saturated Fat with Cardiovascular Disease. American Journal of Clinical Nutrition, 91, 535-546. https://doi.org/10.3945/ajen.2009.27725

[5] Chaiseri, S. and Dimick, P. (1989) Lipids and Hardness Characteristics of Cocoa Butters from Different Geographic Regions. Journal of the American Oil Chemists Society, 66, 1771-1776. https://doi.org/10.1007/BF02660745

[6] Ghina Hajjara, B., Rizkb, T., Bejjanib, J. and Akoka, S. (2020) Metabisotopomics of Triacylglycerols from Animal Origin: A Simultaneous Metabolomic and Isotopic Profiling Using ${ }^{13} \mathrm{C}$ INEPT. Food Chemistry, 315, Article ID: 126325. https://doi.org/10.1016/j.foodchem.2020.126325

[7] Caytan, E. (2006) Détermination de la distribution intramoléculaire du ${ }^{13} \mathrm{C}$ en abondance naturelle par RMN quantitative, Nantes.

[8] Merkle, H., Wei, H., Garwood, M. and Ugurbilet, K. (1992) B ${ }_{1}$-Insensitive Heteronuclear Adiabatic Polarization Transfer for Signal Enhancement. Journal of Magnetic Resonance (1969), 99, 480-494. https://doi.org/10.1016/0022-2364(92)90204-K

[9] Burum, D. and Ernst, R. (1980) Net Polarization Transfer via a J-Ordered State for Signal Enhancement of Low-Sensitivity Nuclei. Journal of Magnetic Resonance (1969), 39, 163-168. https://doi.org/10.1016/0022-2364(80)90168-7

[10] Lipp, E.M. and Anklan, E. (1998) Review of Cocoa Butter and Alternative Fats for Use in Chocolate-Part A. Compositional Data. Food Chemistry, 62, 73-97.

https://doi.org/10.1016/S0308-8146(97)00160-X

[11] Balayssac, S., Déjean, S., Lalande, J., Gilard, V. and Malet-Martino, M. (2013) A Toolbox to Explore NMR Metabolomic Data Sets Using the R Environment. Chemometrics and Intelligent Laboratory Systems, 126, 50-59. https://doi.org/10.1016/j.chemolab.2013.04.015

[12] Paillard, N.M.M. (1979) Biosynthèse des produits volatils de la pomme: Formation des alcools et des esters à partir des acides gras. Phytochemistry, 18, 1165-1171. https://doi.org/10.1016/0031-9422(79)80127-2

[13] Mazliak, P. (1980) Annales de la nutrition et de Palimentation, 34, 189-206.

[14] Merchak, N., Silvestre, V., Loquet, D., Rizk, T., Akoka, S. and Bejjani, J. (2017) A Strategy for Simultaneous Determination of Fatty Acid Composition, Fatty Acide Position, and Position-Specific Isotope Contents in Triacylglycerol Matrices by ${ }^{13} \mathrm{C}-\mathrm{NMR}$. Analytical and Bioanalytical Chemistry, 409, 307-315. https://doi.org/10.1007/s00216-016-0005-Z

[15] Diomande, D., Antheaume, I., Leroux, M., Lalande, J., Balayssac, S., Remaud, G.S. and Tea, I. (2015) Multi-Element, Multi-Compound Isotope profiling as A Means to Distinguish the Geographical and Varietal Origin of Fermented Cocoa (Theobroma cacao L.) Beans. Food Chemistry, 188, 576-582. https://doi.org/10.1016/j.foodchem.2015.05.040

[16] O’Leary, M. (1988) Carbon Isotopes in Photosynthesis. BioScience, 38, 328-336. https://doi.org/10.2307/1310735

[17] Kendall, C., Silva, S.R. and Kelly, V.J. (2001) Carbon and Nitrogen Isotopic Compositions of Particulates Organic Matter in Four Large River Systems Across the 
United States. Hydrological Processes, 15, 1301-1346.

https://doi.org/10.1002/hyp.216

[18] Rostad, C.E., Leenheer, J.A. and Daniel, S.R. (1997) Organic Carbon and Nitrogen Content Associated with Colloids and Suspended Particulates from the Mississippi River and Some of Its Tributaries. Environmental Science \& Technology, 31, 3218-3225. https://doi.org/10.1021/es970196b

[19] Cerling, T.E., Harris, J.M., Macfadden, B.J., Leakey, M.G., Quade, J., Eisenmann, V. and Ehleringer, J.R. (1997) Global Vegetation Change through the Miocenel Pliocene Boundary. Nature, 389, 153-158. https://doi.org/10.1038/38229 